\title{
Impact of Efficiency on Voluntary Disclosure of Non-Banking Financial Company-Microfinance Institutions in India
}

\author{
Arpita Sharma and Shailesh Rastogi *(D) \\ Symbiosis Institute of Business Management Pune, Symbiosis International, Deemed University, Pune 412115, \\ India; arpitasharma@sibmpune.edu.in \\ * Correspondence: krishnasgdas@gmail.com
}

check for

updates

Citation: Sharma, Arpita, and Shailesh Rastogi. 2021. Impact of Efficiency on Voluntary Disclosure of Non-Banking Financial

Company-Microfinance Institutions in India. Journal of Risk and Financial Management 14: 289. https:// doi.org/10.3390/jrfm14070289

Academic Editors: Erhan Kilinçarslan and Mohamed H. Elmagrhi

Received: 16 March 2021

Accepted: 12 June 2021

Published: 24 June 2021

Publisher's Note: MDPI stays neutral with regard to jurisdictional claims in published maps and institutional affiliations.

Copyright: (c) 2021 by the authors. Licensee MDPI, Basel, Switzerland. This article is an open access article distributed under the terms and conditions of the Creative Commons Attribution (CC BY) license (https:/ / creativecommons.org/licenses/by/ $4.0 /)$.

\begin{abstract}
This paper investigates how the financial and social efficiency of firms influence the extent of the voluntary disclosure of Non-Banking Financial Companies-Micro Financial Institutions (NBFCMFI). The study constructed an unweighted index of voluntary disclosure to estimate the level of voluntary disclosure of all of the included firms from the years 2015-2019. The financial and social efficiency, which is analogous to the technical efficiency of production theory and analyses both sustainability and outreach, respectively, was estimated using data envelopment analysis (DEA). The panel data analysis was completed, and a positive association of financial efficiency was estimated. The social efficiency was found to have no relationship to the voluntary disclosure level. This paper contributed to the literature by providing new determinants of voluntary disclosure. The study examines the econometric model and suggests that financially sustainable firms that utilize these resources well are more open to outsiders, while socially efficient firms are reluctant to voluntary disclosure, which also includes social activities, and consider this as a wasteful activity. The findings of this study are relevant to industry practitioners and regulators, who need to think upon the sustainability of this crucial sector by meeting the dual objectives of financial and social performance. This study is helpful to all stakeholders as well as for the government, who can use the results to design additional rules for the NBFC-MFI. This study will also help firms to design disclosure strategies to ascertain goodwill and less cost of capital, with easy access to funds.
\end{abstract}

Keywords: voluntary disclosure; efficiency; panel data analysis; data envelopment analysis; NBFC-MFI

\section{Introduction}

In the last decade, the Indian microfinance sector experienced extraordinary progress and took its fair position in the financial inclusion setup of the country. Commercial banks do their part in meeting the credit needs of financially deprived people who cannot produce collateral. However, the banks alone are unable to bridge this gap, which exists due to a mismatch in the supply and demand of the required funds. This vacuum is filled by microfinancial institutions, through various grass root level programmes. The microfinance industry across the globe, and specifically in India, is crucial to financial inclusion and helps in economic development (Young 2010). The microfinance sector in India has seen phenomenal growth, with an increase in credit disbursement and an increasing number of beneficiaries (Sa-Dhan 2019).

The Indian microfinance sector is divided into two complex structures: regulated and unregulated. The regulated institutions are either deposit or non-deposit-taking microfinance entities, but the most dominant form, suggested by the Reserve Bank of India (RBI), is non-deposit-taking NBFC-MFI. It is observed that the NBFC-MFI industry is changing its form, as some of the giant NBFC-MFI are converting into small finance banks. At the same time, some of these firms, such as Credit Access Grameen Bank, are becoming larger. The RBI (2011) has created NBFC-MFI, a new form of micro-financial institutions, and has set up various guidelines after the Andhra Pradesh crisis in 2010 and based on 
suggestions given in the Malegam Committee Report. The RBI (2015a) has defined the code of conduct of NBFC-MFI and suggested efficiency improvement, which includes improving their processes and operations to reduce the cost of these firms. This suggests that regulators are acting in line with the changing microlending environment in India and introducing new entities. However, the bigger question for these entities is if they can survive in this volatile market of microlending. NBFC-MFI (Quayes 2012) have to meet the bottom line of the dual objectives of sustainability and outreach for their survival. Prior studies (Gutiérrez-Nieto et al. 2009; Widiarto and Emrouznejad 2015) have examined the first MFI objective of sustainability through financial efficiency, and the second MFI objective was estimated through social efficiency.

With the changing regulatory environment, the industry has raised concerns from the investors and donors and has emphasized the utilization of resources by these MFI. The motivation of this study is to relieve MFI from external subsidies. This results in better resource utilization and the disclosure of the same information to external parties and stakeholders to ensure and substantiate the regulatory compliance and performance of the MFI (Quayes and Hasan 2014). The disclosures must comply with the RBI, and the MFI should maintain a transparent and good corporate governance system; hence, meaningful disclosure by the MFI verify the firm's credibility (Das 2011).

\subsection{Regulations for NBFC-MFI in India}

Non-banking financial companies are made and comply to rules under the RBI (2015a). The directions are systematically designed for the non-deposit-taking companies. The prudential norms / directions are applicable to the non-banking financial companies defined under clause (45) of Section 2 of the companies Act 18 of 2013 (RBI 2015b). The RBI suggests additional regulations depending on the type of NBFC. NBFC-MFI are the non-deposit-taking companies registered under the Section 25 of the companies Act, 1956. Special directions are given in chapter IX of the direction received from RBI (2016) for NBFC-MFI. The guidelines specify the disclosure and transparency norms of these entities. NBFC-MFI should also follow the directions issued by the Financial Inclusion and Development Department (FIDD). NBFC-MFI need to become members and comply with the code of conduct for the self-regulatory organisations (SRO), which are recognized by the RBI. NBFC-MFI need to follow the Fair Practice Code (FPC), which is mentioned in directions of chapter IV of the RBI (2011).

\subsection{Motivation}

Corporate disclosure norms provide a safeguard to the reputation and proper functioning of a rapidly expanding industry, providing benefits to poor borrowers. These disclosures provide transparency in the system for donors, policymakers, which puts the stakeholders at ease, and help in tapping the required resources for the sustenance of the MFI. Unlike banks that are supported by deposits, credit disbursement, and the government, MFI are dependent on market credit operations and self-sustainability. Thus, NBFC-MFI need to emphasize both financial sustainability and social outreach, as the investors have a vested interest in this.

Corporate disclosure is mainly categorized as obligatory disclosure and voluntary disclosure. Annual reports are a source of all of the information that comes under regulation and compliance. Voluntary corporate disclosure is a set of information revealed over and above the regulatory requirements. This voluntary disclosure can include a firm's financial disclosures, non-financial disclosures, strategic disclosures, etc. (Beyer et al. 2010; Hossain 2008); hence it is required for researchers to understand the characteristics of the firms that go the extra mile and disclose this information. Michels (2012) suggests that the lending activities in the group lending scenario are positively impacted by voluntary disclosure.

Prior studies explain various factors of the firms that impact the level of voluntary disclosure. Quayes and Hasan (2014) establish the association between the financial performance and the financial disclosures of global MFI. Charumathi and Ramesh (2020) 
establish that higher value firms positively impact the voluntary disclosure of the firms in India. Chen et al. (2014) argue that certain non-high tech firms in less developed regions working with associations or networks such as banks, the government, or other companies, are reluctant to disclose voluntarily due to a lack of motivation. Hence for these firms, value is negatively related to voluntary disclosure. This negative association is due to the close watch of competitors. It is noted that the low disclosure standards of the microfinance industry affect overall social welfare. Thus, the current study is motivated by the importance of the existing literature on voluntary disclosure and demands an urgent need to study the similar affect in the context of the Indian NBFC-MFI industry. This study aims to answer the following research questions: First, how efficiently are the MFI utilizing the resources available to them? Second, what are the different levels of financial and social efficiency mapping the dual objectives of the firms? Third, what is the level of voluntary disclosure maintained by the MFI? Fourth, what kind of firms disclose more after finding out the impact of the level of financial and social efficiency on the level of voluntary disclosure?

As such, the current study feels an urge to find the association of efficiency and level of voluntary disclosure for NBFC-MFI in India, where efficiency is taken as a performance indicator for MFI (Hartarska and Mersland 2012) and can be taken as one of the variables in the accounted literature for determinants of voluntary disclosure.

The research questions lead to the following objectives:

1. To find out the level of the efficiency levels of the NBFC-MFI;

2. To find out the level of voluntary disclosure in the NBFC-MFI;

3. To find out the association between the efficiency and level of voluntary disclosure.

The second section of this paper includes a literature review and hypothesis development. Section three explains the research methodology, and section four presents the data analysis and the results. The managerial implications are mentioned in section four, and the conclusion, limitations, and future scope of this paper is presented in the last section.

\section{Literature Review and Hypothesis Development}

\subsection{Theoritical Development: Voluntary Disclosures}

This section explains the theories behind voluntary disclosure, which help in discovering the features of the firms that effect the level of voluntary disclosures. This section also explains the prior empirical research in the voluntary disclosure field.

By nature, voluntary disclosure is a communication tool to promote a company's ideas to potential stakeholders for the long-term sustainability and growth of the company (Abeysekera and Guthrie 2005). By definition, voluntary corporate disclosure is the additional evidence released by the company that is beyond the scope of the mandatory disclosures required under the law (Boesso and Kumar 2007; Hossain and Hammami 2009; Chau and Gray 2002; Barako et al. 2006). Theoretically, voluntary disclosure is grouped into economic theories (such as signaling theory, capital need theory, and agency theory) or socio-political theory (such as legitimacy theory, institutional theory, political theory, and stakeholder theory). Agency theory is one of the widely researched theories that supported the concept of voluntary disclosure (Jensen and Meckling 1976). It provides the importance of information disclosure and discusses the information asymmetry that leads to adverse selection and moral hazards. Researchers describe that asymmetric information among borrowers and lenders might create severe issues of adverse selection in the industry, such as microfinance institutions, which are group lending based (Berger and Udell 1995; Petersen and Rajan 1994). Therefore, good quality information disclosure (Healy and Palepu 2001) helps in reducing information asymmetry. The Theory of signalling suggests (Verrecchia 1983) that voluntary corporate disclosure acts as 'signals' sent by the managers to the potential lenders; hence information disclosure is one of the key strategic decisions taken by the firm (Beyer et al. 2010).

Md Zaini (2017) shows that voluntary disclosure is done to gain the stakeholder's feelings confidence, status, and legitimacy for the organisation (Faisal et al. 2012). Nurhayati 
et al. (2015) highlight that developing countries show a low level of voluntary disclosure, as the firms are concerned about the unfavorable impact on the firm's reputation (Zaini et al. 2018; Mondal and Ghosh 2014).

The amount of voluntary disclosure is empirically tested with corporate governance measures and has shown a positive association (Barako et al. 2006). Higher institutional ownership increases voluntary disclosure. The determinants of voluntary disclosure by Kenyan companies derive that the act of disclosing more voluntarily is positively associated with the shares held by foreigners and institutional shareholders, the level of leverage, the size of the firm, the external audit by audit firms, the profitability, and the liquidity (Barako et al. 2006; Abeywardana and Panditharathna 2016). Eng and Mak (2003) showed that firms larger in size disclose more, and firms with low debt also disclose more. Quayes and Hasan (2014) tested the endogenous relationship between financial disclosures and financial performance of microfinance institutions in 75 countries and inferred that better disclosures have a positive impact on operational performance and that better financial performance improves the disclosure quality.

Some studies (Quayes and Hasan 2014; Gutiérrez-Nieto et al. 2009) showed the internet disclosures of microfinance institutions and found out that NGOs reveal more social information, and for-profit organizations are better at financial information disclosures. They also noted that disclosures in the media are correlated with the amount of technological development of the country and the amount of legal transparency of the region in which the MFI operates.

\section{Voluntary Disclosure Index}

To estimate the level and quality of disclosure, indices were created. Some disclosure indices are self-constructed or can be directly taken from previous studies (Abeywardana and Panditharathna 2016; Al-Akra and Hutchinson 2013; Al-Akra et al. 2010; Tsang 1998). Healy and Palepu (2001) stated that there is greater confidence in a self-constructed index compared to the readily available indices.

Content analysis is used to calculate the scores and level of disclosures (Basalamah and Jermias 2005; Hackston and Milne 1996). Content analysis is a technique used to codify the texts present in the annual reports into different themes or categories (Weber 1990).

The amount of voluntary disclosure observes the firm's quality and credibility disclosed through different categories and can be measured through an index. These categories can be (1) internal and external information of the firm; (2) financial and non-financial information; (3) social, strategic, operational, futuristic information, etc. (Abeywardana and Panditharathna 2016; Singhvi and Desai 1971; Charumathi and Ramesh 2015).

Relevancy comes from the scores given by experts on these items. It has been identified that the quantity and quality of voluntary disclosures relate to the type and complexity of the firm. Researchers believe and explain that annual reports remain the object of the study (Beattie et al. 2004).

There are two ways of measuring the index: one is weighted, and another is unweighted. The weighted index is used for a specific purpose, and the weights are given based on the requirements of the researcher. The unweighted index is neutral and gives all of the items equal importance.

\subsection{Efficiency}

Traditional performance indicators are not enough for estimating the performance of MFI. One of the widely used techniques was ratio analysis, which suffers from the major problem of benchmarking and the handling of multiple inputs and outputs (Thanassoulis 2001; Otto 2011). Efficiency is defined as the measure to check the ability of the firm to reach the output(s) through the minimum amount of input resources. Efficiency is simply the operational efficiency of the firm in the industry, which explains the process of the utilization of resources and the optimal allocation of those resources (Achabal et al. 1984). Caballer-Tarazona et al. (2010) and Golany and Storbeck (1999) studied efficiency as the 
parameter to explain the performance of the decision-making units (DMU). Kumar and Gulati (2010) measured the efficiency to calculate the overall performance of Indian banks. The performance was assessed and measured through efficiency (Mouzas 2006; Sharma et al. 2020). Studies confirm that firms that are non-high technology-based and that work in networks (guanxi) that are based on governments and close allies and interpersonal ties are resistant towards disclosing information, and therefore, show a negative association of the firm value with voluntary disclosure (Chen et al. 2014). This is because of the following reasons: (i) the marginal benefits of the increased disclosure are less than the marginal costs of the firm (Dye 1986; Verrecchia 1983; Chen et al. 2014) and, (ii) the firms may not have significant information that need a disclosure (Dye 1985). The microfinance institutions with dual objectives measure financial performance (Louis et al. 2013) with the combination of inputs and outputs required for the efficiency estimation. The expenses on the personnel, total assets, non-interest expenses, total liabilities, operating costs, and number of employees are some of the indicators taken for the inputs (Louis et al. 2013; Lebovics et al. 2016). Gross loans, gross interests, net income, dividend income, and financial revenue are some of the indicators taken as the outputs for estimating financial performance. Social efficiency (Gutiérrez-Nieto et al. 2009; Lebovics et al. 2016), which is measured through an input-output combination of average annual income and average loan balance per borrower, respectively, which is analogous to the technical efficiency (Servin et al. 2012) under production theory.

Social efficiency is explained by the social indicators of firms (Ravallion 2003). Microfinance studies explain that firms sometimes compromise on the social mission of serving the beneficiaries, and only financial efficiency is focused on. Financial efficiency measures the intensity with which the firms generate revenues utilizing their assets. Some researches (Otero and Rhyne 1994; Von Pischke 1996; Morduch 2000; Woller 2002; Mersland and Strøm 2010; Hermes et al. 2011, 2018) endorse the trade-off between social and financial efficiency. Researchers have shown that the firms with high financial efficiency might have low outreach but have larger loans. This simply means that the outreach of the organizations is negatively related to financial efficiency (Hermes et al. 2011), although some researchers argue this and suggest that the firms showing good social impact also show financial efficiency (Gutiérrez-Nieto et al. 2009).

\subsubsection{Efficiency Measurement through Data Envelopment Analysis}

Efficiency is measured through a non-parametric technique called data envelopment analysis (DEA) (Charnes et al. 1978). The firm of which the efficiency is measured is known as the decision-making unit (DMU). These DMUs can be non-profit or for-profit organizations, and DEA is used to measure the overall efficiency of them. Charnes et al. (1978) considered the constant return to scale model, which takes the small sample size (CCR model) and assumes that efficiency can be measured with two models, input minimization and output maximization, that will have the same efficiencies. An alternative assumption of Banker et al. (1984) is the use of the variable returns to scale (VRS) model, which is suitable for larger sample sizes. This model is also known as the BCC model. Ferdousi (2013) measured the overall efficiency under the assumption of the CCR, and pure technical and scale efficiencies were measured through VRS. Variables such as operating expenses and the number of staff (inputs) and gross loan portfolio and the number of active borrowers (outputs) were taken for the study. There are other approaches to measure efficiency as well. Data from 435 MFI were collected (Mix Market TM) over the period of 1997-2007. The study used Stochastic Frontier Analysis (BC Model), Battese and Coelli (1995), to measure the efficiency of the MFI since it controls random effects and measurement errors. In the analysis, cost efficiency was taken as the parameter for efficiency in terms of how close the actual costs of the lending activities of an MFI relative to the costs of a best-practice MFI were, making the case that it produced identical output under the same conditions. It was also discovered that the MFI that had lower average loan balances 
were less efficient Hermes et al. (2011). Additionally, MFIs with more female clients were also less efficient.

\subsubsection{Impact of Efficiency on Voluntary Disclosure}

Baiman and Verrecchia (1996) demonstrated how the level of disclosure is affected by the production efficiency of firms. The production efficiency of firms is inversely related to the level of disclosure. When the level of disclosure increases, it leads to an increase in liquidity, and it lowers the cost of capital. This leads to a decline in the gains to insiders and further increases in the moral hazard of the manager, which decreases efficiency. In contrast to this, Gutiérrez-Nieto et al. (2009) found no association between disclosure with social efficiency. Goldstein and Yang (2019) studied the disclosure and market efficiency and concluded that market efficiency and disclosure share a negative association. This is due to uninformed retail investors. According to the Friedman style, investors consider voluntary social responsibility activities as wasteful. Jaggi and Freedman (1982) study the negative correlation between pollution disclosures (quantitative and qualitative) and economic performance. The economic performance is derived from indicators like ROA, ROE, and EBIT. This is supported by Ingram and Frazier (1983), who also established a weak negative correlation between the content disclosed in the annual reports and the economic performance. Ullman (1985) established a negative association between social disclosure (which is quasi-mandated) and economic performance.

\subsection{Research Gap and Hypothesis Design}

The authors find that there is a dearth of voluntary disclosure studies in India. Prior studies have given a lot of determinants of voluntary disclosure, but very few studies are done on micro-financial institutions. There is no such study present on the NBFC-MFI which studies the pattern of the voluntary disclosure of a for-profit organisation with a social objective. The literature review has helped in finding the following research gaps for the study. First, the literature does not have any voluntary disclosure studies in the MFI sector. Second, the financial performance is checked, but the social performance is not, even though for-profit organisations like NBFC-MFI have a dual objective. Third, efficiency is a superior measure to check performance, and the relationship between efficiency and voluntary disclosure is not present in the literature. Fourth, the literature review done across the dimensions of voluntary disclosures, index construction, efficiency, and their relationship creates the notion that a self-constructed voluntary disclosure is not available for NBFC-MFI, which are for-profit companies and have dual objectives to meet. Hence the current study tries to test the relationship between voluntary disclosure and the financial efficiency and social efficiency of NBFC-MFI in India.

Hypothesis 1 (H1): Financial efficiency is significantly associated with the voluntary disclosure of the firm.

Hypothesis 2 (H2): Social efficiency is significantly associated with the voluntary disclosure of the firm.

This will help the sector understand how for-profit MFI are making a tradeoff between social and financial efficiency, and how it impacts the voluntary disclosure, or if it works the other way. Thus, a high or low score of voluntary disclosure (VD) can meet the conflicting twin goals of the MFI, i.e., servicing the underprivileged and meeting the expectations of investors. Thus, this study will focus on the impact of efficiency on voluntary disclosure on the efficiency of the NBFC-MFI in India. 


\section{Research Design and Methodology}

\subsection{Research Design}

The study adopts amixed method wherein both quantitative and qualitative study is undertaken. The study is divided into two parts. The qualitative part includes the in-depth interviews of experts to construct the content analysis for measuring the level of voluntary disclosure. The quantitative part includes an estimation of efficiency by using DEA and the relationship of the efficiency with the level of voluntary disclosure through panel data analysis

\subsubsection{Construction and Measurement of Levels Voluntary Disclosure}

Part one of the study is to estimate the magnitude of voluntary disclosure of NBFCMFI. An index for voluntary disclosure was constructed. The definition used for the construction of voluntary corporate disclosure was the discretionary release of a different set of information. This can be financial and non-financial, futuristic, etc. This information is over and above the mandatory disclosures.

The study used an unweighted index. This study method is known as the dichotomous method. The disclosure of an item in the annual report is given given ' 0 ', and non-disclosure of an item is given ' 1 '. If a study does not have a specific user group, then unweighted indexes are made, and each user group can assign weights and make sense out of it for their specific user group (Cooke 1989; Abeysekera and Guthrie 2005; Jones and Shoemaker 1994; Owusu-Ansah 1998; Raffournier 1995; Hossain et al. 1994).

The study focused on the micro-financial intuitions that are regulated by the RBI and NABARD. The regulated MFI are divided into entities like commercial banks, small finance banks, and cooperatives that are deposit-taking. Others are non-deposit taking, which are non-bank financial companies (NBFC) (RBI 2015a, 2016). One of the major challenges of the non-deposit-taking entities is to raise funds for the firm and finding donors and investors. Thus, these non-deposit-taking entities face challenges meeting the dual financial and social objectives. As such, the current study aims to find out the efficiency levels of these firms. The study also aims to find out the level of transparency that the firms maintain for the stakeholders and find out how the efficiency levels of the firm impact the level of voluntary disclosure. The study considers 25 registered NBFC-MFI with the Reserve Bank of India from 2015 to 2019, with a total of 125 observations, which constitutes an adequate sample size for the study (Nunnally 1967). This suggests that per indicator, there are 10 observations required. It is noted that these are unlisted entities, and due to data insufficiency, data from only 46 firms were available on CMIE Prowess. The study dropped firms if the firms did not fit the following criteria:

(i) Firms need availability of the annual reports from 2015-2019.

(ii) Firms need to be registered with the RBI from 2015-2019.

The disclosure studies used the annual reports and various studies confirm this (Kassarjian 1977; Srinivasan 2006). The annual reports underwent content analysis. The themes and categories were identified. The categories have a group of statements.

$$
\text { VD Score }=\sum \text { Score of all categories } \div \text { Number of items }
$$

Equation (1) explains the formula to calculate the voluntary disclosure (VD) score.

An extensive literature review was done to develop the voluntary disclosure index by the firm. The following steps were taken to construct the voluntary disclosure: First, the disclosure norms of the NBFC-MFI are according to the Fair Practice Code of Conduct as per the RBI. The microfinance direction of 2011 is considered for transparency and directions. Second, the study took in-depth interviews of the experts, financial professional, and accountants across the industry, and third, the disclosure index was made by referring to the literature (Hossain et al. 1994; Buckland et al. 2000; Barako 2007; Firer and Meth 1986). The 97-item index was sent to experts, and their feedback was taken to create a list of 74 items. The final list of items was created and divided into nine categories 
that were derived from (Abeywardana and Panditharathna 2016). The methodology was adopted from Barako (2007). The index has nine categories (Table 1) which consist of: background about the NBFC-MFI, corporate strategy, financial performance, forwardlooking information, social performance, human intellectual and capital, corporate social responsibility, competitive environment, and outlook, and risk management. The different categories adopted for the study cover all the detailed narratives, financial, non-financial, strategic, forward-looking, and the competitive perspectives of the organisation. Studies support that these are major areas that constitute the voluntary disclosure index (Elfeky (2017); Barako (2007); Htay et al. (2012); Sinha and Gadarowski (2010); Quayes and Hasan (2014)).

Table 1. The categories for voluntary disclosure index.

\begin{tabular}{cc}
\hline Major Categories & Resources \\
\hline $\begin{array}{c}\text { A Background about the NBFC-MFI corporate } \\
\text { information (08): }\end{array}$ & Elfeky (2017); Barako (2007) \\
\hline B Corporate Strategy (04): & Elfeky (2017). \\
\hline C Financial Performance (10) & Elfeky (2017); Barako (2007); Quayes and \\
Hasan (2014).
\end{tabular}

Note the authors' contribution. Categories for the VD index.

\subsubsection{Efficiency Estimation}

In the second part of the study, the efficiency of the firms was measured through a non-parametric approach, DEA. For ascertaining the efficiencies, input and output combinations were derived from the literature given in Table 2. The efficiency is taken as financial efficiency and social efficiency. The input parameters to measure both the efficiencies were the number of employees, operating expenses, and total assets. The output parameters for financial efficiency and social efficiency were the gross loan portfolio, income from financial service and average loans and advances, and active borrowers, respectively. The DEA estimated the efficiency of decision-making units (DMUs) for a particular year. The study measured the efficiency of the NBFC-MFI. First, the efficiency was measured by taking the constant return to scale technical efficiency (CRSTE), which applies to the small samples (CCR model). The CRSTE is considered to be the global measurement for firm performance (Huguenin 2012). Second, the orientation model for the current study is an output orientation model because the firms selected for the study were granted a level of input, and their objective was to maximize output (Huguenin 2012). The technical efficiency for the CCR and BCC output-oriented model is given in Equations (2) and (3).

$$
\begin{array}{cc} 
& z o=\varphi+\in(\mathrm{eTs}++\mathrm{eTs}-) \\
\max & \Phi Y \mathrm{Yo}-\mathrm{Y} \lambda+s+=0 \\
\varphi, \lambda, s+, s- & \mathrm{X} \lambda+s-=\mathrm{Xo} \\
\text { Subjet to } & \lambda, s+, s-\geq 0
\end{array}
$$


Equation (2) explains the output-oriented CCR Model (Charnes et al. 1978). The variable $\varphi$ indicates the increase in the output to achieve efficiency.

$$
\begin{array}{cc} 
& z o=\varphi+\in(\mathrm{eTs}++\mathrm{eTs}-) \\
& \Phi \mathrm{Yo}-\mathrm{Y} \lambda+s+=0 \\
\max & \mathrm{X} \lambda+s-=\mathrm{Xo} \\
\varphi, \lambda, s+, s- & T \lambda=1 \\
\text { Subjet to } & \lambda, s+, s-\geq 0
\end{array}
$$

Equation (3) explains the output-oriented BCC Model (Banker et al. 1984).

The study measured the efficiency as financial efficiency and social efficiency by taking different input-output combinations aiming to meet the dual objectives of the sustainability and the outreach of the firm. The input and output combinations for estimating the financial efficiency for the current study are mentioned in Table 2a and the input-output combinations for measuring the social efficiency are mentioned in Table $2 \mathrm{~b}$.

Table 2. (a) Input and output combinations for financial efficiency estimation; (b) Input and output combinations for social efficiency estimation.

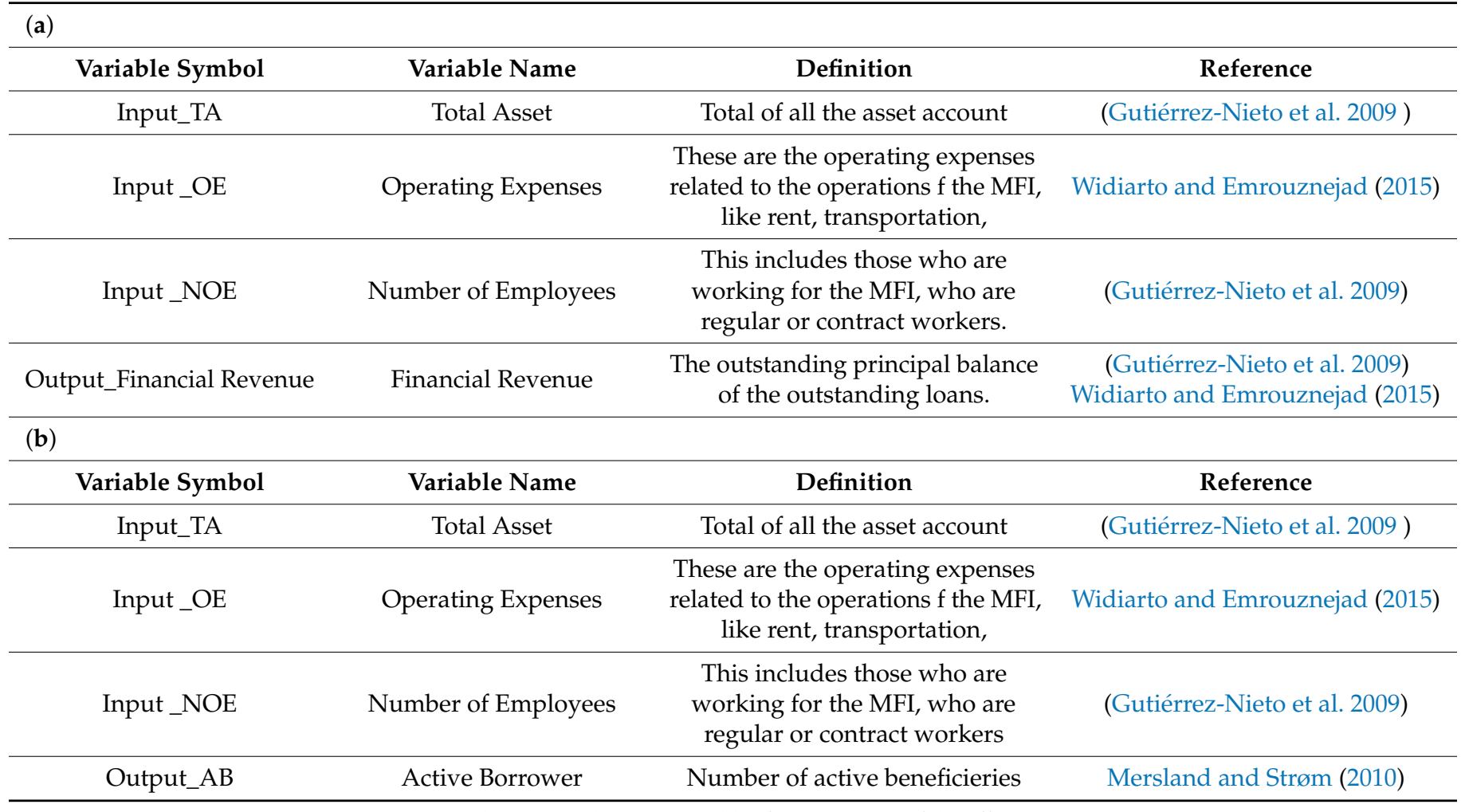

Note authors' contribution: variables for estimation of the efficiency.

\subsubsection{Firm-Specific Variables for the Study}

The studies in the area of voluntary disclosure take into account the firm-specific variables such as size (El-Diftar et al. 2017; Hossain and Reaz 2007; Ingram and Frazier 1983). It is observed that a firm's size is positively related to voluntary disclosure (Quayes and Hasan 2014). The study has taken the number of employees as aproxy of the size. The firms with a higher number of employees disclosed more. Profitability shows a positive relationship with voluntary disclosure (Camfferman and Cooke 2002; Soliman 2013). The younger firms, unlike the older firms, do not show a strong corporate governance structure, so age also impacts voluntary disclosures (Sharma et al. 2019; El-Diftar et al. 2017; Hossain and Reaz 2007). Studies done on microfinance institutions show that the Gross Loan Portfolio positively impacts the disclosures of the firms, Quayes and Hasan (2014). The 
literature does not show a clear association of the leverage with the disclosures. Some studies show a positive association between the leverage and the voluntary disclosure (Foster 1986). The study measured leverage as the ratio of debt and equity.

\subsubsection{Impact of Efficiency on Voluntary Disclosure}

In the final stage, the impact of financial and social efficiency on the level of voluntary disclosure was tested. The software used for the study was STATA.

The voluntary disclosure index was constructed through interviews and the existing literature. The content analysis was completed to measure the scores of each firm from 2015-2019. The level of disclosure was taken as LOGVD, which was measured as the log value of the voluntary disclosure score measures for each year from the annual reports. Efficiency scores (financial and social) were taken from the DEA software. The model also considers some firm-specific variables (refer to Section 3.1.3). Equation (4) attempts to examine the model that finds the impact of financial efficiency and social efficiency on voluntary disclosure.

\section{Data Analysis and Results}

\subsection{Voluntary Disclosure Index and Its Reliability}

The index was created with nine categories, and the scores were calculated (Equation (1)) by completing a content analysis of the annual reports of each firm over five years.

The reliability of the index of voluntary disclosure was measured. The Cronbach alpha of the voluntary index was 0.717 , which was more than the cut-off value of 0.7 and was considered good, considering the internal consistency of the items in the index used (Cronbach 1951).

\subsection{Measurement of Efficiencies of the NBFC-MFI}

\subsubsection{Input and Output Variables for DEA}

The descriptive statistics in Table 3 explain the maximum, minimum, and standard deviation of the input and output for the financial and social efficiency, respectively.

Table 3. Descriptive statistics of inputs and outputs for the years 2015-2019 for financial efficiency and social efficiency estimation.

\begin{tabular}{|c|c|c|c|c|c|}
\hline & \multicolumn{3}{|c|}{ Both FE \& SE Model } & \multirow{2}{*}{$\begin{array}{c}\text { FE Model } \\
\text { GLP(O) }\end{array}$} & \multirow{2}{*}{$\begin{array}{c}\text { SE Model } \\
\mathrm{AB}(\mathrm{O})\end{array}$} \\
\hline & TA(I) & OE(I) & NOE(I) & & \\
\hline MAX & $1.12247 \times 10^{11}$ & $7,831,669,413$ & 16,021 & $30,366,400,000$ & $7,401,000$ \\
\hline MIN & $52,878,201$ & $6,097,109$ & 20 & $3,803,391$ & 46 \\
\hline MEAN & $12,511,771,130$ & $814,673,003.2$ & 1981 & $2,382,702,459$ & 706,451 \\
\hline SD & $19,572,137,459$ & $1,386,105,619$ & 2760 & $4,286,968,015$ & $1,239,852$ \\
\hline
\end{tabular}

Note: Authors' calculations using SPSS. The brackets specify the O = Output and I = Input Variable for both financial efficiency (FE) and the social efficiency model (SE). TA, OE, and GLP are in the Rs crore denomination, and the NOE and $\mathrm{AB}$ are in numbers.

\subsubsection{The Validity of the Efficiency Evaluation Model}

This section explains the validity in terms of model specification. First, we introduced the isotonicity test to check how the change in the inputs affected the change in the outputs. This was done by measuring the inter-correlation among the input and output variables. Table $4 \mathrm{a}, \mathrm{b}$ explain the correlation among the input and output variables. The results show that the variables are significantly correlated, which validates their association to measure efficiency. 
Table 4. (a) Correlation matrix (financial efficiency)—test of isotonicity; (b) Correlation matrix (social efficiency)—test of isotonicity.

\begin{tabular}{|c|c|c|c|c|}
\hline (a) & & & & \\
\hline & FR_O & TA_I & OE_I & NOE_I \\
\hline FR_O & 1 & & & \\
\hline TA_I & $0.951 * *$ & 1 & & \\
\hline OE_I & $0.897^{* *}$ & $0.858^{* *}$ & 1 & \\
\hline NOE_I & $0.937^{* *}$ & $0.926^{* *}$ & $0.855^{* *}$ & 1 \\
\hline \multicolumn{5}{|l|}{ (b) } \\
\hline & AB_O & TA_I & OE_I & NOE_I \\
\hline AB_O & 1 & & & \\
\hline TA_I & $0.909 * *$ & 1 & & \\
\hline OE_I & $0.862^{* *}$ & $0.858^{* *}$ & 1 & \\
\hline NOE_I & $0.948^{* *}$ & $0.926^{* *}$ & $0.855^{* *}$ & 1 \\
\hline
\end{tabular}

\subsubsection{Efficiency Estimation of NBFC-MFI in India}

The efficiency estimates were measured through DEAP 2.1. DEA estimated the technical efficiency under the output-oriented model and CCR. The efficiency scores were measured by taking two models, financial efficiency and social efficiency, of NBFC-MFI.

Table 5 explains the number of a firm's average technical efficiency under the FE and E model and the mean voluntary disclosure score. The mean disclosure scores were measured every year, and the results show that the mean voluntary disclosure score improved over time from the years 2015 to 2019. The variation is also increased over the years.

Table 5. Technical efficiency of NBFC-MFI and mean VD score from 2015-2019.

\begin{tabular}{|c|c|c|c|c|c|c|c|}
\hline Year & $\begin{array}{c}\text { No of } \\
\text { NBFC-MFI }\end{array}$ & $\begin{array}{c}\text { DMU with Max } \\
\text { Value of } 1 \text { (FE } \\
\text { Model) }\end{array}$ & $\begin{array}{c}\text { Mean } \\
\text { CRSTE-FE } \\
\text { Model }\end{array}$ & $\begin{array}{c}\text { DMU with Max } \\
\text { Value of } 1 \text { (SE } \\
\text { Model) }\end{array}$ & $\begin{array}{c}\text { Mean } \\
\text { CRSTE-SE } \\
\text { Model }\end{array}$ & $\begin{array}{c}\text { Mean VD } \\
\text { Score }\end{array}$ & $\begin{array}{c}\text { STD of VD } \\
\text { Score }\end{array}$ \\
\hline 2015 & 25 & 1 & 0.48 & 3 & 0.78 & 26.96 & 9.10 \\
\hline 2016 & 25 & 3 & 0.63 & 4 & 0.81 & 33.28 & 12.47 \\
\hline 2017 & 25 & 5 & 0.78 & 5 & 0.80 & 36.08 & 12.27 \\
\hline 2018 & 25 & 5 & 0.88 & 3 & 0.59 & 36.16 & 12.06 \\
\hline 2019 & 25 & 4 & 0.89 & 3 & 0.61 & 42.52 & 13.81 \\
\hline
\end{tabular}

Note Authors' calculations: DEAP 2.1.STD is the standard deviation of the voluntary disclosure scores.

The financial and social efficiency is measured at CRSTE. Columns three and five show the number of DMU benchmarked with a technical efficiency score of 1 at CRSTE. It can be seen through Table 5 that the number of firms reaching the maximum score, (1), is under the FE model more than the SE model. The average CRSTE score is in the range from 0.485 in 2015 to 0.803 in 2019 for the FE model, which infers that a $51.5 \%$ increase in the output in 2015 and 10.1\% of the increase in the output in 2019 is required at the given level of input usage to attain efficiency. However, for the SE model, the CRSTE shows that the average CRSTE is around 0.785 in the year 2015 and 0.634 in the year 2019, which shows that an increase of approximatly $21.5 \%$ in the output in the year 2015 and a 38.6\% increase in the social output in the year 2019 is required by the firms to reach efficiency while maintaining the input.

Table 6 explains the returns to scale and technical efficiency under the financial efficiency and social efficiency model. Under the FE model, the average efficiency score under CRSTE means that NBFC-MFI can maximize $10.1 \%$ of the output (FR) by maintaining the same level of input (TA, OE, and NOE). Under the VRSTE model, the NBFC-MFI can maximize $7.9 \%$ of the output while maintaining the input. Under the SE model, the average 
CRSTE implies that the NBFCI-MFI output of (AB) can be maximized by $38.6 \%$ while maintaining the same level of input (TA, OE, and NOE).

The outcomes of Table 6 show that DMUs NBFC-MFI 5, 10, 11, 18, and 23 are showing returns to scale, which indicates if the firm needs to increase or decrease the scale of the firm for minimizing the firms average costs. 13 NBFC-MFIs show decreasing returns to scale in technical efficiency under the FE model, whereas under the SE model, none of the NBFC-MFI show an increasing return to scale.

Table 6. Efficiency summary for the year 2019.

\begin{tabular}{|c|c|c|c|c|c|c|c|c|}
\hline \multirow{2}{*}{ FIRM } & CRSTE & VRSTE & SCALE & RTS & CRSTE & VRSTE & SCALE & RTS \\
\hline & \multicolumn{3}{|c|}{ Financial Efficiency } & \multicolumn{5}{|c|}{ Social Efficiency } \\
\hline NBFC-MFI1 & 1 & 1 & 1 & 0 & 1 & 1 & 1 & 0 \\
\hline NBFC-MFI2 & 0.86 & 1 & 0.861 & -1 & 0.60 & 1 & 0.60 & -1 \\
\hline NBFC-MFI3 & 1 & 1 & 1 & 0 & 0.08 & 0.24 & 0.33 & -1 \\
\hline NBFC-MFI4 & 0.97 & 1 & 0.970 & -1 & 0.63 & 0.83 & 0.76 & -1 \\
\hline NBFC-MFI5 & 0.92 & 0.92 & 0.9975 & 1 & 0.44 & 0.52 & 0.84 & -1 \\
\hline NBFC-MFI6 & 1 & 1 & 1 & 0 & 0.80 & 1 & 0.80 & -1 \\
\hline NBFC-MFI7 & 0.89 & 0.94 & 0.945 & -1 & 0.63 & 0.78 & 0.80 & -1 \\
\hline NBFC-MFI8 & 0.76 & 0.77 & 0.987 & -1 & 0.62 & 0.75 & 0.82 & -1 \\
\hline NBFC-MFI9 & 1 & 1 & 1 & 0 & 0.62 & 0.65 & 0.94 & -1 \\
\hline NBFC-MFI10 & 0.93 & 0.94 & 0.996 & 1 & 0.67 & 0.79 & 0.85 & -1 \\
\hline NBFC-MFI11 & 0.84 & 0.84 & 0.998 & 1 & 0.68 & 0.80 & 0.85 & -1 \\
\hline NBFC-MFI12 & 0.93 & 0.95 & 0.980 & -1 & 0.92 & 1 & 0.92 & -1 \\
\hline NBFC-MFI13 & 1 & 1 & 1 & 0 & 0.90 & 0.99 & 0.90 & -1 \\
\hline NBFC-MFI14 & 0.93 & 0.94 & 0.987 & -1 & 0.50 & 0.62 & 0.80 & -1 \\
\hline NBFC-MFI15 & 0.86 & 0.89 & 0.971 & -1 & 0.66 & 0.87 & 0.76 & -1 \\
\hline NBFC-MFI16 & 0.80 & 0.85 & 0.935 & -1 & 0.52 & 0.70 & 0.74 & -1 \\
\hline NBFC-MFI17 & 1 & 1 & 1 & 0 & 0.74 & 1 & 0.74 & -1 \\
\hline NBFC-MFI18 & 0.91 & 0.92 & 0.994 & 1 & 0.52 & 0.59 & 0.88 & -1 \\
\hline NBFC-MFI19 & 0.74 & 0.75 & 0.988 & -1 & 0.62 & 0.67 & 0.93 & -1 \\
\hline NBFC-MFI20 & 0.93 & 0.99 & 0.946 & -1 & 0.49 & 0.68 & 0.71 & -1 \\
\hline NBFC-MFI21 & 0.91 & 1 & 0.910 & -1 & 0.55 & 0.67 & 0.81 & -1 \\
\hline NBFC-MFI22 & 0.78 & 0.82 & 0.944 & -1 & 0.47 & 0.50 & 0.92 & -1 \\
\hline NBFC-MFI23 & 0.91 & 0.91 & 0.998 & 1 & 0.67 & 0.73 & 0.92 & -1 \\
\hline NBFC-MFI24 & 0.73 & 0.74 & 0.987 & -1 & 0.33 & 0.34 & 0.97 & -1 \\
\hline NBFC-MFI25 & 0.80 & 0.80 & 1 & 0 & 0.59 & 0.63 & 0.94 & -1 \\
\hline Mean & 0.89 & 0.92 & 0.976 & & 0.61 & 0.73 & 0.82 & \\
\hline
\end{tabular}

Note Authors' calculations: DEAP 2.1 CRSTE $=$ technical efficiency from CRS DEA; VRSTE $=$ technical efficiency from VRS DEA; SCALE = scale efficiency $=$ crste $/$ vrste; RTS $=$ returns to scale; $1=$ Increasing returns to scale, $-1=$ decreasing return to scale, $0=$ means constant return to scale.

Table 7 explains the peer summary. The firm that appears the most frequently is the most efficient firm among its peers. Under the FE model, Madhura Microfinance (NBFCMFI 10) is the most efficient NBFC-MFI. Whereas in the SE model, Bharat Microfinance (NBFC-MFI 6) is the most efficient NBFC-MFI and is also the second most efficient firm under the FE model. 
Table 7. Peer Summary.

\begin{tabular}{ccc}
\hline Firm & Peers (FE)-NBFC-MFI & Peers(SE)-NBFC-MFI \\
\hline NBFC-MFI1 & 1. & 1 \\
NBFC-MFI2 & $12,1$. & 1,12 \\
NBFC-MFI3 & 3. & 5,12 \\
NBFC-MFI4 & $21,10,12,15$. & $15,6,1$ \\
NBFC-MFI5 & $10,12,21,15$. & $15,6,1$ \\
NBFC-MFI6 & 6. & 6. \\
NBFC-MFI7 & $6,10,12,22$. & 1,6 \\
NBFC-MFI8 & $6,22,10,15$. & $15,6,1$ \\
NBFC-MFI9 & $1,10,15,22,12$. & $15,1,6$. \\
NBFC-MFI10 & 10. & $6,1$. \\
NBFC-MFI1 & $19,10,1,6$. & $6,1$. \\
NBFC-MFI12 & 19. & 12. \\
NBFC-MFI13 & $19,15,12,15,10$. & $15,1,6$. \\
NBFC-MFI14 & $15,19,21,10,12$. & $15,6,1$. \\
NBFC-MFI15 & 15. & 15. \\
NBFC-MFI16 & $10,17,15,19$. & $1,6$. \\
NBFC-MFI17 & 17. & $15,6,1$. \\
NBFC-MFI18 & $6,10,15,22$. & $12,15,6$. \\
NBFC-MFI19 & 19. & $1,6$. \\
NBFC-MFI20 & $6,10,1$. & $6,1$. \\
NBFC-MFI21 & 21. & $15,6,1$. \\
NBFC-MFI22 & 22. & $6,12,15$. \\
NBFC-MFI23 & $15,22,10,12$. & $6,1,15,12$. \\
NBFC-MFI24 & $19,1,25,10,12$. & $1,15,6$, \\
NBFC-MFI25 & 25. & $1,6$. \\
\hline
\end{tabular}

Note authors' calculation from DEAP 2.1. The table shows the peer summary. Annexure 1 for names of NBFCMFI.

\subsection{Consolidate Panel Regression Results}

In the subsection, the panel regression results are presented. The relationship empirically tests the relationship between voluntary disclosure and efficiency. Some of the variables are dropped due to the presence of a higher value of VIF (variance inflation factor). Table 8 explains the descriptive statistics, and Table 9 explains the panel data estimation.

To establish the relationship, the efficiency scores (measured through DEA) are regressed against the log of VD scores using panel data (Equation (4)). The firm variables are taken as control variables (refer to Section 3.1.3).

Table 8. Descriptive statistics.

\begin{tabular}{cccccc}
\hline Variable & Observations & Mean & $\begin{array}{c}\text { Standard } \\
\text { Deviation }\end{array}$ & Minimum & Maximum \\
\hline Log-VD & 125 & 3.59 & 0.46 & 1.67 & 4.41 \\
Financial Efficiency & 125 & 0.71 & 0.21 & 0.16 & 1 \\
Social Efficiency & 125 & 0.72 & 0.19 & 0.004 & 1 \\
Profitability & 125 & 0.018 & 0.03 & -0.15 & 0.11 \\
Log-GLP & 125 & 22.18 & 2.10 & 13.64 & 35.95 \\
Number of personal & 125 & 1981.78 & 2759.85 & 20 & 16,021 \\
Leverage & 125 & 4.63 & 4.26 & -36.57 & 9.13 \\
\hline
\end{tabular}

Note: the table explains the descriptive statistics of the variables used for the panel estimate.

Table 9 shows the panel estimates for Model 1. LOGVD it is the dependent variable, FECRS $_{\text {it }}$ and SECRS ${ }_{\text {it }}$ are independent variables, and the error term is $\varepsilon_{i t}$ for $i=1,2,3$, etc. Cross-sectional units $(\mathrm{M})$ are observed for dated periods, $t=1,2,3$, etc. $T$ and dit capture the firm effect, and 乙it captures time effect (Equation (4)). Model 2 and Model 3 test the model at different levels of voluntary disclosure score. LOG_HVD explains the firms with the high level of voluntary disclosure scores, and LOG_LVD explains the firm's low level of disclosure scores. 


$$
\begin{aligned}
& \text { Model 1LOGVD } \text { it }=\alpha+\beta_{1} \text { FE_CRS }_{-i t}+\beta_{2} \text { SE_CRS }_{-i t}+\gamma \text { it Firm specific }+\delta \text { it }+\zeta \text { it }+\varepsilon_{\text {it }} \\
& \text { Model 2LOGHVD } i t=\alpha+\beta_{1} \text { FE_CRS_it }_{-}+\beta_{2} \text { SE_CRS_it }+\gamma \text { it Firm specific }+\delta \text { it }+\zeta \text { it } \\
& \text { Model 3LOGLVD it }=\alpha+\beta_{1} \text { FE_CRS_it }_{-}+\beta_{2} \text { SE_CRS_it }_{-}+\gamma \text { it Firm specific }+\delta \text { it }+\zeta \text { it }
\end{aligned}
$$

The selection of the applicable model is explained by the likelihood test, which helped in choosing between pooled OLS and fixed effect. After a fixed test was chosen among the two, Hausman was completed, which suggested the presence of a fixed effect regression model. The model fit of the fixed effect was tested. The Breusch Pagan LM test results signified the presence of a fixed effect. The serial correlation was tested through the Wooldridge test, and the results show that no serial correlation was present. The fixedeffect model showed an absence of heteroscedasticity (Wooldridge 2010).

Table 9. Panel estimate.

\begin{tabular}{cccc}
\hline Independent Variable Log-VD & Coefficient & Standard Error & t Ratio \\
\hline Constant & 3.00 & 0.29 & $10.16(0.000)$ \\
Financial Efficiency & 0.40 & 0.12 & $3.30(0.001)$ \\
Social Efficiency & -0.16 & 0.14 & $-1.15(0.253)$ \\
Log-GLP & 0.020 & 0.01 & $1.54(0.128)$ \\
Leverage & -0.002 & 0.005 & $-0.48(0.635)$ \\
Profitability & 2.05 & 0.79 & $2.58(0.011)$ \\
Number of employees & 0.00004 & 0.00001 & $2.85(0.005)$ \\
\hline Test for differing groups & $11.08^{* *}$ & BP Test & $112.18^{* *}$ \\
Hausman Test & $62.36^{* *}$ & $\mathrm{R}^{2}$ & 0.41 \\
Wooldridge Test for & 0.184 & Number of & 125 \\
autocorrelation & 5 & observation & \\
Number of years & & \\
\hline
\end{tabular}

Note: The table shows the estimates and the fixed effect model. Statistical significance ${ }^{* *}$ are significant at the $5 \%$ level. Social efficiency (constant return to scale). FECRS, financial efficiency, (constant return to scale). LOGVD = Log of Voluntary disclosure score. The model explains the model fit indicators. Wooldridge test (Wooldridge 2010; Drukker 2003) of autocorrelation was performed.

\subsection{Robustness of the Findings}

The robustness is checked through sensitivity analysis. In this analysis, various other forms of proxies are created from the disclosure index to check the robustness Albassam (2014). The robustness of the model is tested by creating sub-indices (Hassan and Marston 2019), the higher-level index and low-level index.

Models 1, 2, and 3 (Table 10) report the findings of the different sub-indices. It can be observed that the two sub-indices were created with a higher and lower level of voluntary disclosure. The financial efficiency was found to have a relationship that is significant and positive with Log-VD in all three models. The social efficiency is found to have no significant relationship with Log-VD. The Log-GLP level of the gross loan portfolio was found to have a significant relationship in Model 3, whereas models 1 and 2 do not show any significant relationship between Log-GLP and Log-VD. The number of employees (a proxy for size) was found to have a positive and significant relationship with Log-VD in Models 1, 2, and 3. Profitability also has a positive and significant relationship with Log-VD in all three models, although leverage was found to have a negative and nonsignificant effect on the Log-VD in Model 1. In models 2 and 3, leverage was positive but non-significant relation with the Log-VD. The models were found to be similar in obtaining the results. This supports the robustness of the findings. 
Table 10. Robustness check with a lower and higher level of disclosures.

\begin{tabular}{cccc}
\hline $\begin{array}{c}\text { Independent Variable } \\
\text { Log-VD }\end{array}$ & $\begin{array}{c}\text { Whole Index } \\
\text { (Fixed Effect) } \\
\text { Model 1 }\end{array}$ & $\begin{array}{c}\text { Low-Level Index } \\
\text { Model 2 }\end{array}$ & $\begin{array}{c}\text { High-Level Index } \\
\text { Model 3 }\end{array}$ \\
\hline Constant & $10.16^{* *}$ & $15.64^{* *}$ & $12.64^{* *}$ \\
Financial Efficiency (FECRS) & $3.30^{* *}$ & $2.22^{* *}$ & $1.59^{* *}$ \\
Social Efficiency (SECRS) & -1.15 & -0.45 & -0.93 \\
Log-GLP & 1.54 & 0.71 & $1.52^{* *}$ \\
Leverage & -0.48 & 0.92 & 0.85 \\
Profitability & $2.58^{* * *}$ & 1.02 & 1.62 \\
Number of employee & $2.85^{* *}$ & $3.27^{* *}$ & $2.96^{* *}$ \\
\hline F test & $11.08^{* *}$ & $7.40^{* *}$ & $6.65^{* *}$ \\
Number of years & 5 & 5 & 5 \\
$\mathrm{R}^{2}$ & $0.41^{* *}$ & 0.60 & 0.49 \\
Wald Chi2 & $30.18^{* *}$ & $12.74^{* *}$ & $46.86^{* *}$ \\
\hline
\end{tabular}

Note: ** and ${ }^{* * *}$ indicates the $p$-value significant at $5 \%$ levels and $1 \%$ level respectively. The robustness is checked with high level and low level of disclosure models.

Panel A (Table 11) reports the fixed effect estimates, where the independent variables, called efficiency estimates, are taken at constant levels of returns, and Panel B estimates (Table 11) the fixed effect but at the variables returns to scale. Both models report a positive and significant impact on the financial efficiency (CRS and VRS) on Log-VD. The panels also found a positive and significant impact on the profitability and the number of employees (a proxy for size) on Log-VD. The panels show the similarity in the results. Thus, the analysis supports the robustness of the study.

Table 11. Robustness check by comparing the impact of efficiency estimate at a constant return to scale and the variables return to scale on the level of voluntary disclosures.

\begin{tabular}{ccc}
\hline Independent Variable Log-VD & $\begin{array}{c}\text { Efficiency at Constant } \\
\text { Returns to Scale Panel A }\end{array}$ & $\begin{array}{c}\text { Efficiency at Variable } \\
\text { Returns to Scale Panel B }\end{array}$ \\
\hline Constant & $10.16^{* * *}$ & $8.55^{* * *}$ \\
Financial Efficiency & $3.30^{* * *}$ & $3.65^{* * *}$ \\
Social Efficiency & -1.15 & -0.36 \\
Log-GLP & 1.54 & 2.07 \\
Leverage & -0.48 & 0.06 \\
Profitability & 2.58 & $2.67^{* * *}$ \\
Number of employees & 2.85 & $3.81^{* * *}$ \\
\hline F test & & $11.41^{* *}$ \\
Hausman Test & $62.36^{* *}$ & $15.13^{* *}$ \\
Wooldridge test for autocorrelation & 0.184 & 0.384 \\
Breusch-Pagan Test & $112.18^{* *}$ & $108.94^{* *}$ \\
R & 0.41 & 0.42 \\
Number of observations & 125 & 125 \\
\hline
\end{tabular}

Note: Panel A has taken financial and social efficiency estimates at a constant return to scale (CRS). Panel B has taken financial and social efficiency estimates at the variables to the scale (VRS). $P$-value is significant at the ***,** at $1 \%$ and $5 \%$ levels.

\subsection{Endogeneity}

The problem of endogeneity is usual in disclosure studies. This study has checked for this problem. This problem occurs when the explanatory variables have a high correlation with the error term. This study estimates the 2 SLS and uses the instrumental variable method to check the problem of endogeneity (Brooks 2019). The financial efficiency variable has the Durbin-Wu-Hausman (F statistics $=0.394344$ ) value a insignificant, which shows that the variable is exogenous. The social efficiency variable has Durbin-Wu-Hausman (F statistics $=0.073502$ ) values as insignificant, which shows that the variables are exogenous, and endogeneity is absent. Furthermore, the relevance of the instrument is checked and 
shows that $R^{2}$ statistics are 0.30 and the $F$ statistics are significant at 12.86 , which is more than the threshold of 10 and the critical value of $5 \%$ for Wald test; hence suggesting that the instruments used in the models were not weak.

\section{Implications}

The current study has significant managerial implications. First, it will be relevant for managers to understand the efficiency level of the firm and the firm's benchmarking with their peers. The financial efficiency level is the indicator of the sustainability of the NBFC-MFI, and the social efficiency is an indicator of the outreach levels. Certain firms are efficiently maintaining a higher level of sustainability, and certain firms are increasing outreach.

Second, the study helps to understand the corporate activity of the firms by using various input and output combinations using data envelopment analysis.

Third, the study simplifies the concept of voluntary disclosure by linking it with the performance indicator of efficiency (Han et al. 2016; Goldstein and Yang 2019) and introduces policy implications, where the Indian government with the regulators should take a keen interest and determine specific types of indexing for these firms, which can check disclosure norms. This study suggests that those firms that efficiently use financial resources yield higher-level voluntary disclosure. However, this study fails to establish any relationship between the socially efficient firms and the level of voluntary disclosures. The results are in line with the studies done in Asian countries, which suggest that the companies get less incentive for releasing more information.

In India, the RBI has suggested that these entities can list themselves to any selfregulatory organization-SRO (RBI 2015a) and share details with these institutes. However, the sharing of the data is a voluntary activity, which attracts a lot of governance issues. Therefore, the current study justifies that even if the organizations are efficient, these firms should disclose more information to remove the asymmetry in the financial market and thus attract more investors and donors and lessen the cost of capital. The firms should not consider this voluntary disclosure as a wasteful activity (Ullman 1985; Jaggi and Freedman 1982; Ingram and Frazier 1983). This will endorse a favorable environment for social mobility, which is one of the ultimate objectives of these entities called NBFC-MFI.

\section{Conclusions, Limitations, and Future Scope}

The paper empirically tests the impact of financial efficiency and social efficiency on the voluntary disclosure of the non-banking financial companies-micro-financial institutions over the period 2015 to 2019.

The study concludes that the level of efficiency at CRSTE is measured through data envelopment analysis and shows that the average efficiency of NBFC-MFI in India under the FE model is better than the SE model. This brings a hindrance to the dual objectives of NBFC-MFI.

The study also shows that the average voluntary disclosures by NBFC-MFI are not high but are improving gradually. In the sample of NBFC-MFI, the majority are private limited firms. The financial efficiency is positively associated with the level of voluntary disclosure.

This suggest that the firms that are efficiently utilizing their resources are also open to outsiders and insiders and disclose more voluntarily. This also suggest that these firms are financially sustainable, which tends to maintain transparency. The study does not find any significant impacts on the firms that are socially efficient, which is supported by prior studies (Gutiérrez-Nieto et al. 2009). However, the negative sign of social efficiency (outreach) is because the firms that show good performance believe that voluntary disclosure might not impact their investors and donors, as they believe that disclosing voluntarily is a wasteful activity. The result is supported by (Luo and Chen 1997; Peng and Luo 2000). The studies done on the Chinese guanxi network, which suggests that the firms working in a closed environment and take resources on mutual trust and interpersonal ties disclose less 
voluntarily to decrease the cost of capital and avoid competition. Indian NBFC-MFI also work in a similar environment. They also believe that putting money into social activities only increases the cost. The current study is done on both public and private limited firms, which enforce the presence of more uninformed investors. As the majority of the firms are private, they are closely linked, and therefore, resist disclosing voluntary information.

The fixed-effect model suggests that the impact of efficiency and the specific variables of the firms is fixed over the years.

The study confirms that as the number of employees (a proxy of size) and profitability leads to an increase in the level of voluntary disclosure.

The current study can be extended to a large set of companies of similar nature and with other forms of microfinance institutions. With the recent advancement and regulations for microlenders, the study can be further tested in a global setup. The productivity of the firms can also be tested, and the reasons for the efficiency change can be gauged. The current study constructs an unweighted index. Other researchers can construct a weighted index and the model can be empirically tested for different geography and different dataset.

Author Contributions: Conceptulization, Formal analysis, Investigation, method, presentation, software, writing original draft, writing review and editing-A.S.; Concept building, Supervision, validation, software, reviewing - S.R. Both authors have read and agreed to the published version of the manuscript.

Funding: This research received no external funding.

Institutional Review Board Statement: This clause is not applicable.

Informed Consent Statement: This is not applicable.

Data Availability Statement: This is not applicable.

Conflicts of Interest: The authors declare no conflict of interest.

\section{Abbreviations}

$\begin{array}{ll}\text { S. NO } & \text { List of NBFC-MFI } \\ \text { NBFC-MFI1 } & \text { Adhikar Microfinance Pvt. Ltd. } \\ \text { NBFC-MFI2 } & \text { Annapurna Finance Pvt. Ltd. } \\ \text { NBFC-MFI3 } & \text { Agora Microfinance India Ltd. } \\ \text { NBFC-MFI4 } & \text { Asirvad Micro Finance Ltd. } \\ \text { NBFC-MFI5 } & \text { Belstar Microfinance Pvt. Ltd. } \\ \text { NBFC-MFI6 } & \text { Bharat Financial Inclusion Ltd. [Merged] } \\ \text { NBFC-MFI7 } & \text { Chaitanya India Fin Credit Pvt. Ltd. } \\ \text { NBFC-MFI8 } & \text { Fusion Micro Finance Pvt. Ltd. } \\ \text { NBFC-MFI9 } & \text { M Power Micro Finance Pvt. Ltd. } \\ \text { NBFC-MFI10 } & \text { Madura Micro Finance Ltd. } \\ \text { NBFC-MFI11 } & \text { Margdarshak Financial Services Ltd. } \\ \text { NBFC-MFI12 } & \text { Muthoot Microfin Ltd. } \\ \text { NBFC-MFI13 } & \text { Pahal Financial Services Pvt. Ltd. } \\ \text { NBFC-MFI14 } & \text { Saija Finance Pvt. Ltd. } \\ \text { NBFC-MFI15 } & \text { Satin Creditcare Network Ltd. } \\ \text { NBFC-MFI16 } & \text { Sonata Finance Pvt. Ltd. } \\ \text { NBFC-MFI17 } & \text { Spandana Sphoorty Financial Ltd. } \\ \text { NBFC-MFI18 } & \text { Samasta Microfinance Ltd. } \\ \text { NBFC-MFI19 } & \text { Svasti Microfinance Pvt. Ltd. } \\ \text { NBFC-MFI20 } & \text { Svatantra Microfin Pvt. Ltd. } \\ \text { NBFC-MFI21 } & \text { Village Microfinance Pvt Ltd. } \\ \text { NBFC-MFI22 } & \text { Creditaccess Grameen Ltd. } \\ \text { NBFC-MFI23 } & \text { Jagaran Microfin Pvt. Ltd. } \\ \text { NBFC-MFI24 } & \text { Navachetana Microfin Services Pvt. Ltd. } \\ \text { NBFC-MFI25 } & \text { Shikhar Microfinance Pvt. Ltd. }\end{array}$




\section{References}

Abeysekera, Indra, and James Guthrie. 2005. An empirical investigation of annual reporting trends of intellectual capital in Sri Lanka. Critical Perspectives on Accounting 16: 151-63. [CrossRef]

Abeywardana, N. L. Erandi, and K. M. Panditharathna. 2016. The extent and determinants of voluntary disclosures in annual reports: Evidence from banking and finance companies in Sri Lanka. Accounting and Finance Research 5: 147-62. [CrossRef]

Achabal, Dale, John M. Heineke, and Shelby H. McIntyre. 1984. Issues and perspectives on retail productivity. Journal of Retailing 60: 107-29.

Al-Akra, Mahmoud, and Patrick Hutchinson. 2013. Family firm disclosure and accounting regulation reform in the Middle East: The case of Jordan. Research in Accounting Regulation 25: 101-7. [CrossRef]

Al-Akra, Mahmoud, Ian A. Eddie, and Muhammad Jahangir Ali. 2010. The influence of the introduction of accounting disclosure regulation on mandatory disclosure compliance: Evidence from Jordan. The British Accounting Review 42: 170-86. [CrossRef]

Albassam, Waleed. 2014. Corporate Governance, Voluntary Disclosure and Financial Performance: Ban Empirical Analysis of Saudi Listed Firms Using a Mixed-Methods Research Design. Doctoral dissertation, University of Glasgow, Glasgow, UK.

Baiman, Stanley, and Robert E. Verrecchia. 1996. The relation among capital markets, financial disclosure, production efficiency, and insider trading. Journal of Accounting Research 34: 1-22. [CrossRef]

Banker, Rajiv D., Abraham Charnes, and William Wager Cooper. 1984. Some models for estimating technical and scale inefficiencies in data envelopment analysis. Management Science 30: 1078-92. [CrossRef]

Barako, Dulacha Galgalo. 2007. Determinants of voluntary disclosures in Kenyan companies annual reports. African Journal of Business Management 1: 113-28.

Barako, Dulacha Galgalo, Phil Hancock, and H. Y. Izan. 2006. Factors influencing voluntary corporate disclosure by Kenyan companies. Corporate Governance: An International Review 14: 107-25. [CrossRef]

Basalamah, Anies S., and Johnny Jermias. 2005. Social and environmental reporting and auditing in Indonesia: Maintaining organizational legitimacy? Gadjah Mada International Journal of Business 7: 109-27. [CrossRef]

Battese, George Edward, and Tim J. Coelli. 1995. A model for technical inefficiency effects in a stochastic frontier production function for panel data. Empirical Economics 20: 325-32. [CrossRef]

Beattie, Vivien, Bill McInnes, and Stella Fearnley. 2004. A methodology for analysing and evaluating narratives in annual reports: A comprehensive descriptive profile and metrics for disclosure quality attributes. Accounting Forum 2 8: 205-36. [CrossRef]

Berger, Allen N., and Gregory F. Udell. 1995. Relationship lending and lines of credit in small firm finance. Journal of Business 68: 351-81. [CrossRef]

Beyer, Anne, Daniel A. Cohen, Thomas Z. Lys, and Beverly R. Walther. 2010. The financial reporting environment: Review of the recent literature. Journal of Accounting and Economics 50: 296-343. [CrossRef]

Boesso, Giacomo, and Kamalesh Kumar. 2007. Drivers of corporate voluntary disclosure. Accounting, Auditing E Accountability Journal 20: 269-96.

Brooks, Chris. 2019. STATA Guide for Introductory Econometrics for Finance. Cambridge: Cambridge University Press.

Buckland, Roger, Mishiel Suwaidan, and Lydia Thomson. 2000. Companies' Voluntary Disclosure Behaviour and Raising Equity Capital in the Amman Financial Market. Research in Accounting in Emerging Economies 4: 247-66.

Caballer-Tarazona, Maria, Ismael Moya-Clemente, David Vivas-Consuelo, and Isabel Barrachina-Martínez. 2010. A model to measure the efficiency of hospital performance. Mathematical and Computer Modelling 52: 1095-102. [CrossRef]

Camfferman, Knees, and Terence E. Cooke. 2002. An analysis of disclosure in the annual reports of UK and Dutch companies. Journal of International Accounting Research 1: 3. [CrossRef]

Charnes, Abraham, William W. Cooper, and Edwardo Rhodes. 1978. Measuring the efficiency of decision making units. European Journal of Operational Research 2: 429-44. [CrossRef]

Charumathi, Balakrishnan, and Latha Ramesh. 2015. On the determinants of voluntary disclosure by Indian companies. Asia-Pacific Journal of Management Research and Innovation 11: 108-16. [CrossRef]

Charumathi, Balakrishnan, and Latha Ramesh. 2020. Impact of voluntary disclosure on valuation of firms: Evidence from Indian companies. Vision 24: 194-203. [CrossRef]

Chau, Gerald. K., and Sidney J. Gray. 2002. Ownership structure and corporate voluntary disclosure in Hong Kong and Singapore. The International Journal of Accounting 37: 247-65. [CrossRef]

Chen, Jean J., Xinsheng Cheng, Stephen X. Gong, and Youchao Tan. 2014. Do higher value firms voluntarily disclose more information? Evidence from China. The British Accounting Review 46: 18-32. [CrossRef]

Cooke, Terence. E. 1989. Disclosure in the corporate annual reports of Swedish companies. Accounting and Business Research 19: 113-24. [CrossRef]

Cronbach, Lee J. 1951. Coefficient alpha and the internal structure of tests. Psychometrika 16: 297-334. [CrossRef]

Das, Debabrata. 2011. Informal Microfinance in Assam: Empirical Evidence from Nalbari and Baksa Districts. Chennai: Centre for Micro Finance, Institute of Financial Management and Research.

Drukker, David M. 2003. Testing for serial correlation in linear panel-data models. The Stata Journal 3: 168-77. [CrossRef]

Dye, Ronald A. 1985. Disclosure of nonproprietary information. Journal of Accounting Research 23: 123-45. [CrossRef]

Dye, Ronald A. 1986. Proprietary and nonproprietary disclosures. Journal of Business 59: 331-66. [CrossRef] 
El-Diftar, Doaa, Eleri Jones, Mohamed Ragheb, and Mohamed Soliman. 2017. Institutional investors and voluntary disclosure and transparency: The case of Egypt. Corporate Governance: The International Journal of Business in Society 17: 134-51. [CrossRef]

Elfeky, Mostafa I. 2017. The extent of voluntary disclosure and its determinants in emerging markets: Evidence from Egypt. The Journal of Finance and Data Science 3: 45-59. [CrossRef]

Eng, Li Li, and Yuen Teen Mak. 2003. Corporate governance and voluntary disclosure. Journal of Accounting and Public Policy 22: 325-45. [CrossRef]

Faisal, Faisal, Grey Tower, and Rusmin Rusmin. 2012. Legitimising corporate sustainability reporting throughout the world. Australasian Accounting, Business and Finance Journal 2: 19-34.

Ferdousi, Farhana. 2013. Performance of Microfinance Institutions in Asia: DEA based efficiency analysis. In Proceedings of the 2013 International Conference on the Modern Development of Humanities and Social Science. Paris: Atlantis Press. [CrossRef]

Firer, C., and G. Meth. 1986. Information disclosure in annual reports in South Africa. Omega 14: 373-82. [CrossRef]

Foster, George. 1986. Financial Statement Analysis. 2/e. New Delhi: Pearson Education India.

Golany, Boaz, and James E. Storbeck. 1999. A data envelopment analysis of the operational efficiency of bank branches. Interfaces 29: 14-26. [CrossRef]

Goldstein, Itay, and Liyang Yang. 2019. Good disclosure, bad disclosure. Journal of Financial Economics 131: 118-38. [CrossRef]

Gutiérrez-Nieto, Begona, Carlos Serrano-Cinca, and Cecilio Mar Molinero. 2009. Social efficiency in microfinance institutions. Journal of the Operational Research Society 60: 104-19. [CrossRef]

Hackston, David, and Markus J. Milne. 1996. Some determinants of social and environmental disclosures in New Zealand companies. Accounting, Auditing \& Accountability Journal 9: 77-108.

Han, Bing, Ya Tang, and Liyan Yang. 2016. Public information and uninformed trading: Implications for market liquidity and price efficiency. Journal of Economic Theory 163: 604-43. [CrossRef]

Hartarska, Valentina, and Roy Mersland. 2012. Which governance mechanisms promote efficiency in reaching poor clients? Evidence from rated microfinance institutions. European Financial Management 18: 218-39. [CrossRef]

Hassan, Omaima A., and Claire Marston. 2019. Corporate financial disclosure measurement in the empirical accounting literature: A review article. The International Journal of Accounting 54: 1950006. [CrossRef]

Healy, Paul M., and Krishna G. Palepu. 2001. Information asymmetry, corporate disclosure, and the capital markets: A review of the empirical disclosure literature. Journal of Accounting and Economics 31: 405-40. [CrossRef]

Hermes, Niels, Robert Lensink, and Alijar Meesters. 2011. Outreach and efficiency of microfinance institutions. World Development 39: 938-48. [CrossRef]

Hermes, Niels, Robert Lensink, and Alijar Meesters. 2018. Financial development and the efficiency of microfinance institutions. In Research Handbook on Small Business Social Responsibility. Cheltenham: Edward Elgar Publishing.

Hossain, Mohammed. 2008. The extent of disclosure in annual reports of banking companies: The case of India. European Journal of Scientific Research 23: 659-80.

Hossain, Mohammed, and Helmi Hammami. 2009. Voluntary Disclosure in the Annual Reports of an Emerging Country: The Case of Qatar. Advances in Accounting, Incorporating Advances in International Accounting 25: 255-65. [CrossRef]

Hossain, Mohammed, and Masrur Reaz. 2007. The determinants and characteristics of voluntary disclosure by Indian banking companies. Corporate Social Responsibility and Environmental Management 14: 274-88. [CrossRef]

Hossain, Mahmud, Lin Mei Tan, and Mike Adams. 1994. Voluntary Disclosure in an Emerging Capital Market: Some Empirical Evidence from Companies Listed on the Kuala Lumpur Stock Exchange. Advances in International Accounting 29: 334-51.

Htay, Sheila Nu Nu, Min Zaw Aung, Hafiz Majdi Ab Rashid, and Muhamad Akhyar Adnan. 2012. The impact of corporate governance on the voluntary accounting information disclosure in Malaysian listed banks. Global Review of Accounting and Finance 3: 128-42.

Huguenin, Jean-Marc. 2012. Data Envelopment Analysis (DEA): A Pedagogical Guide for Decision Makers in the Public Sector. Chavannesprès-Renens: Institut de Hautes Études en Administration Publique Lausanne, vol. 276.

Ingram, Robert W., and Katherine Beal Frazier. 1983. Narrative disclosures in annual reports. Journal of Business Research 11: 49-60. [CrossRef]

Jaggi, Bikki, and Martin Freedman. 1982. An analysis of the informational content of pollution disclosures. Financial Review 17: 142-52. [CrossRef]

Jensen, Michael C., and William H. Meckling. 1976. Theory of the firm: Managerial behavior, agency costs and ownership structure. Journal of Financial Economics 3: 305-60. [CrossRef]

Jones, Michael Jones, and Paul A. Shoemaker. 1994. Accounting narratives: A review of empirical studies of content and readability. Journal of Accounting Literature 13: 142.

Kassarjian, Harold H. 1977. Content analysis in consumer research. Journal of Consumer Research 4: 8-18. [CrossRef]

Kumar, Sunil, and Rachita Gulati. 2010. Measuring efficiency, effectiveness and performance of Indian public sector banks. International Journal of Productivity and Performance Management 59: 51-74. [CrossRef]

Lebovics, Maxime, Niels Hermes, and Marek Hudon. 2016. Are financial and social efficiency mutually exclusive? A case study of Vietnamese microfinance institutions. Annals of Public and Cooperative Economics 87: 55-77. [CrossRef]

Louis, Philippe, Alex Seret, and Bart Baesens. 2013. Financial efficiency and social impact of microfinance institutions using selforganizing maps. World Development 46: 197-210. [CrossRef]

Luo, Yadong, and Min Chen. 1997. Does guanxi influence firm performance? Asia Pacific Journal of Management 14: 1-16. [CrossRef] 
Md Zaini, Syeliya Binti. 2017. The level of Voluntary Disclosure by Malaysian Listed Family-Controlled Companies. Doctoral dissertation, University of Waikato, Hamilton, New Zealand.

Mersland, Roy, and Reider Ø Strøm. 2010. Microfinance mission drift? World Development 38: 28-36. [CrossRef]

Michels, Jeremy. 2012. Do unverifiable disclosures matter? Evidence from peer-to-peer lending. The Accounting Review 87: $1385-413$. [CrossRef]

Mondal, Amitava, and Santanu Kumar Ghosh. 2014. Determinants of intellectual capital disclosure practices of Indian companies. Journal of Commerce and Accounting Research 3: 25-36.

Morduch, Jonathan. 2000. The microfinance schism. World Development 28: 617-29. [CrossRef]

Mouzas, Stefanos. 2006. Efficiency versus effectiveness in business networks. Journal of Business Research 59: 1124-32. [CrossRef]

Nunnally, Jum. 1967. Psychometric Theory. New York: McGraw-Hill.

Nurhayati, Ratna, Grantley Taylor, and Greg Tower. 2015. Investigating social and environmental disclosure practices by listed Indian textile firms. The Journal of Developing Areas 49: 361-72. [CrossRef]

Otero, Maria, and Elisabeth Rhyne. 1994. The New World of Microenterprise Finance; Building Healthy Financial Institutions for the Poor. No. 332.1091724 N532. Sterling: Kumarian Press.

Otto, Sascha. 2011. A speculative efficiency analysis of the London Metal Exchange in a multi-contract framework. International Journal of Economics and Finance 3: 3-16. [CrossRef]

Owusu-Ansah, Stephen. 1998. The impact of corporate attribites on the extent of mandatory disclosure and reporting by listed companies in Zimbabwe. The International Journal of Accounting 33: 605-31. [CrossRef]

Peng, Mike W., and Yadong Luo. 2000. Managerial ties and firm performance in a transition economy: The nature of a micro-macro link. Academy of Management Journal 43: 486-501.

Petersen, Mitchell A., and Raghuram G. Rajan. 1994. The benefits of lending relationships: Evidence from small business data. The Journal of Finance 49: 3-37. [CrossRef]

Quayes, Shakil. 2012. Depth of outreach and financial sustainability of microfinance institutions. Applied Economics 44: 3421-33. [CrossRef]

Quayes, Shakil, and Tanweer Hasan. 2014. Financial disclosure and performance of microfinance institutions. Journal of Accounting $\mathcal{E}$ Organizational Change 10: 314-37.

Raffournier, Bernard. 1995. The determinants of voluntary financial disclosure by Swiss listed companies. European Accounting Review 4: 261-80. [CrossRef]

Ravallion, Martin. 2003. On Measuring Aggregate "Social Efficiency". Policy Research Working Paper; No. 3166. Washington, DC: World Bank.

RBI. 2011. Introduction of New Category of NBFCs-'Non Banking Financial Company-Micro Finance Institutions' (NBFC-MFI) Directions. Available online: https: / rbi.org.in/scripts /NotificationUser.aspx?Id=6857\&Mode=0\#: \{\}:text=234\%20CGM(US) 2011\%20dated,)\%20directions\%2C\%202007\%20and\%20DNBS (accessed on 17 May 2021).

RBI. 2015a. Master Circular-`Non-Banking Financial Company-Micro Finance Institutions' (NBFC-MFIs)—Directions. Available online: https: / / www.rbi.org.in/Scripts/BS_ViewMasCirculardetails.aspx?id=9827\#I (accessed on 1 March 2021).

RBI. 2015b. Master Circular-“'Systemically Important Non-Banking Financial (Non-Deposit Accepting or Holding) Companies Prudential Norms (Reserve Bank) Directions, 2015". Available online: https:/ /rbi.org.in/Scripts/BS_ViewMasCirculardetails aspx?id=9820\#m (accessed on 1 March 2021).

RBI. 2016. Mater Direction-Non Banking Financial Company- Systemically Important Non-Deposit taking Company and Deposit taking Company (Reserve Bank) Directions. Available online: https://rbidocs.rbi.org.in/rdocs/notification/PDFs / $45 \mathrm{MD} 01092$ 016B52D6E12D49F411DB63F67F2344A4E09.PDF (accessed on 2 March 2021).

Sa-Dhan The Bharat Microfinance Report. 2019. Available online: http://www.sa-dhan.net/wp-content/uploads/2020/07/BMR-2019 -Part1-Chater-1.pdf (accessed on 25 February 2020).

Servin, Roselia, Robert Lensink, and Marrit Van den Berg. 2012. Ownership and technical efficiency of microfinance institutions: Empirical evidence from Latin America. Journal of Banking E Finance 36: 2136-44.

Sharma, Arpita, Shubham Bansal, Shukla Deepam, Siddharth Pais, and Sumit Pandey. 2019. A Review of Literature on Corporate Governance in Business. SAMVAD 18: 18-24.

Sharma, Arpita, Shailesh Rastogi, and Nishu Gupta. 2020. Financial Efficiency of Non-Banking Financial Companies-Microfinance Institutions: A Data Envelopment Analysis. Test Engineering and Management 83: 9080-91.

Singhvi, Surendraa S., and Harsha B. Desai. 1971. An empirical analysis of the quality of corporate financial disclosure. The Accounting Review 46: 129-38.

Sinha, Praveen, and Christopher Gadarowski. 2010. The efficacy of regulation fair disclosure. The efficacy of regulation fair disclosure. Financial Review 45: 331-54. [CrossRef]

Soliman, Mohammed. 2013. Firm characteristics and the extent of voluntary disclosure: The case of Egypt. Research Journal of Finance and Accounting 4. [CrossRef]

Srinivasan, Padmini. 2006. Analysis of corporate voluntary disclosure practices: A study of Indian companies. ICFAI Journal of Accounting Research 5: 20-37.

Thanassoulis, Emmanuel. 2001. Introduction to the Theory and Application of Data Envelopment Analysis. Dordrecht: Kluwer Academic Publishers. 
Tsang, Eric W. 1998. A longitudinal study of corporate social reporting in Singapore. Accounting, Auditing E Accountability Journal 11: 624-635.

Ullman, Arieh. 1985. Data in search of a theory: A critical examination of the relationship among social disclosure and economic performance measures. Academy of Management Review 19: 30-39.

Verrecchia, Robert E. 1983. Discretionary disclosure. Journal of Accounting and Economics 5: 179-94. [CrossRef]

Von Pischke, J. D. 1996. Measuring the trade-off between outreach and sustainability of microenterprise lenders. Journal of International Development 8: 225-39. [CrossRef]

Weber, Robert Philip. 1990. Basic Content Analysis. No. 49. Newcastle upon Tyne: Sage.

Widiarto, Indra, and Ali Emrouznejad. 2015. Social and financial efficiency of Islamic microfinance institutions: A Data Envelopment Analysis application. Socio-Economic Planning Sciences 50: 1-17. [CrossRef]

Woller, Gary. 2002. The promise and peril of microfinance commercialization. Small Enterprise Development 13: 12-21. [CrossRef]

Wooldridge, Jeffery Marc. 2010. Econometric Analysis of Cross Section and Panel Data. Cambridge: MIT Press.

Young, Brigitte. 2010. From Microcredit to Microfinance to Inclusive Finance: A Response to Global Financial Openness Global Financial Integration Thirty Years On. Cambridge: Cambridge University Press, pp. 256-69.

Zaini, Syeliya Md, Grant Samkin, Umesh Sharma, and Howard Davey. 2018. Voluntary disclosure in emerging countries: A literature review. Journal of Accounting in Emerging Economies 8: 29-65. [CrossRef] 